\title{
Using Modern Technologies to Complement the Classic Ones in Soil Survey
}

\author{
Mircea MOLDOVAN ${ }^{1,3}$, Cristinel CONSTANDACHE ${ }^{2}$, Vasile ȘIMONCA ${ }^{1,3}$, Ioan TĂUT ${ }^{1,3^{*}}$, Marcel DÎRJA ${ }^{3}$ \\ ${ }^{1}{ }^{\top}$ Marin Drăcea' National Institute for Research and Development in Forestry Cluj \\ 2'Marin Drăcea' National Institute for Research and Development in Forestry Focșani \\ ${ }^{3}$ University of Agricultural Sciences and Veterinary Medicine Cluj-Napoca \\ *corresponding author: ioan_taut90@yahoo.com
}

BulletinUASVM Horticulture 77(1) / 2020

Print ISSN 1843-5254, Electronic ISSN 1843-5394

DOI:10.15835/buasvmcn-hort: 2019.0043

\begin{abstract}
Soil is a complex and dynamic factor that, needs to be studied, analyzed, known and understood. The spreading of soils in the territory is conditioned by the microrelief, lithology characteristics and the hydrographic network. This paper aims to establish the soil survey characteristics and soil evaluation of an agricultural land to be introduced into the national forest fund for afforestation.

In order to achieve the proposed goals, in addition to the classical works, orthophotomaps were used. To establish an afforestation solution, the main site characteristics were determined on the field: altitude, exposure, slope, functional category. These characteristics have been associated with laboratory analyzes to determine soil type, with orthophotomaps measurements and weather data. Analyzing the collected data, the land was enclosed in the bioclimatic hilly region of Turkey oak stand (FD2), where the main species best suited is the Turkey oak, mixed with flowering ash, field maple and pear-tree.
\end{abstract}

Keywords: afforestation, orthophotomaps, soil, soil survey

\section{Introduction}

Soil, a major component of the ecosystem, along with climate and vegetation, is a complex and dynamic factor that, in order to use rationally, needs to be studied, analyzed, known and understood. Within it, a series of biochemical processes are carried out, which help to support life, especially of plants (Keesstra, 2016).

These processes have suffered disturbances due to human activities, since the beginning of the practice of agriculture, being intensified with the increasing need for food. In 2015, the United Nations adopted Sustainable Development Goals (SDGs), which contain 17 objectives, and objective 15 refers to the sustainable use of terrestrial ecosystems. This objective proposes the implementation of measures to stop soil erosion and restore the already eroded ones (Keesstra, 2018).

Worldwide, degraded land is about $75 \%$ of the land area, with a degradation rate of 4.18 million $\mathrm{km}^{2}$ per year. Based on the current degradation rate, it is estimated that by 2050 , degraded land could reach $90 \%$ (europa.eu/rapid/press-release_ IP-18-4202_en.pdf). The natural geographical conditions of Romania, where the sloping land represents up to $67 \%$ of the national territory, amplified by a complex number of natural factors and the need to expand the agricultural areas from the end of the 19th and the beginning of the 20th 


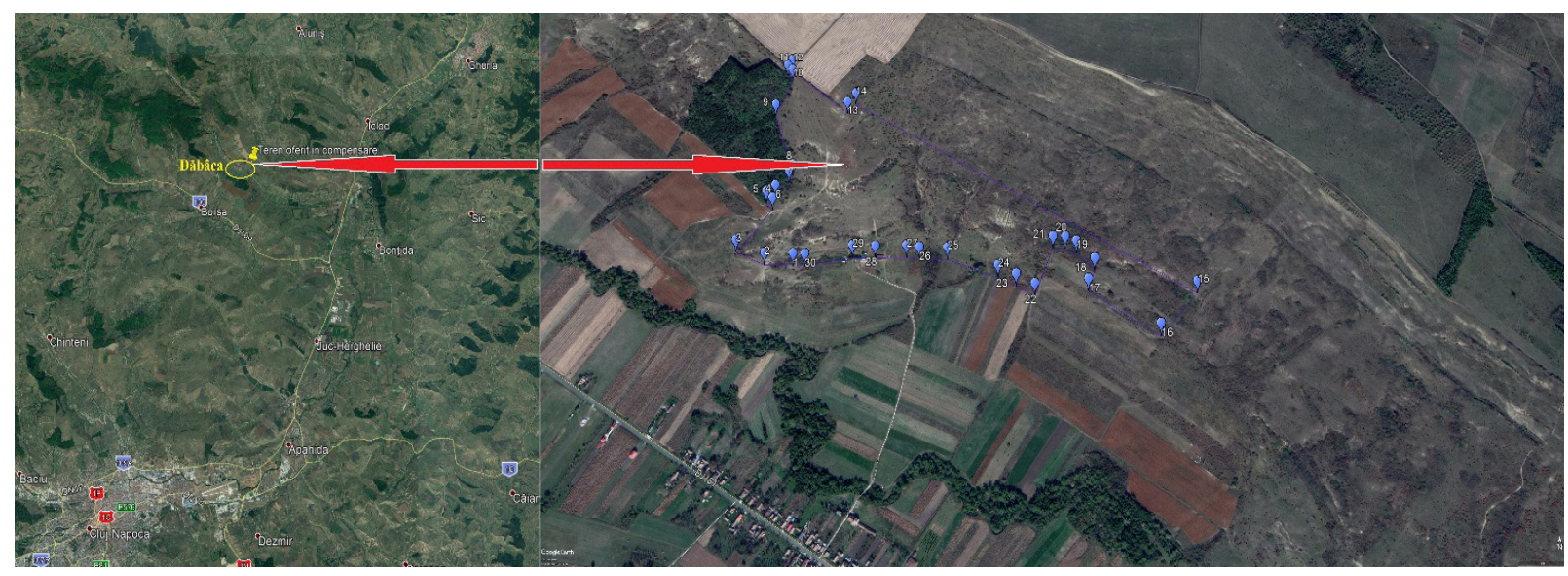

Figure 1. Location of the land

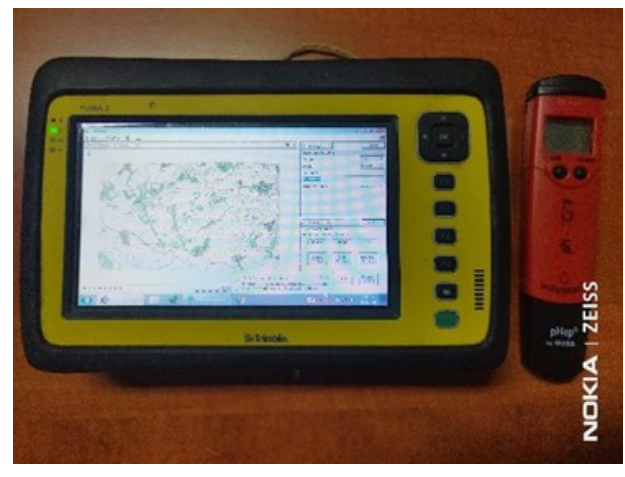

Figure 2. The apparatus used

century, the vegetation and the soils are facing with serious ecological imbalances (Constandache, 2010).

In order to prevent these imbalances from being irreversible, on many grounds ecological reconstruction through forests has been used. For the accomplishment of afforestation it is necessary to know the environmental factors of the planting area.

Ecological reconstruction is essential for the rehabilitation of degraded areas and for the protection of biodiversity, ecosystem services and human welfare. The use of functional features for planning improvement strategies has been suggested, as they represent the main ecological qualities that underpin ecosystem processes and services (Gianni, 2017).

\section{Material and methods}

The land that is the subject of the present study, is located near Dăbâca, a village in Cluj County, with a total area of $25 \mathrm{ha}$, in the surrounding area

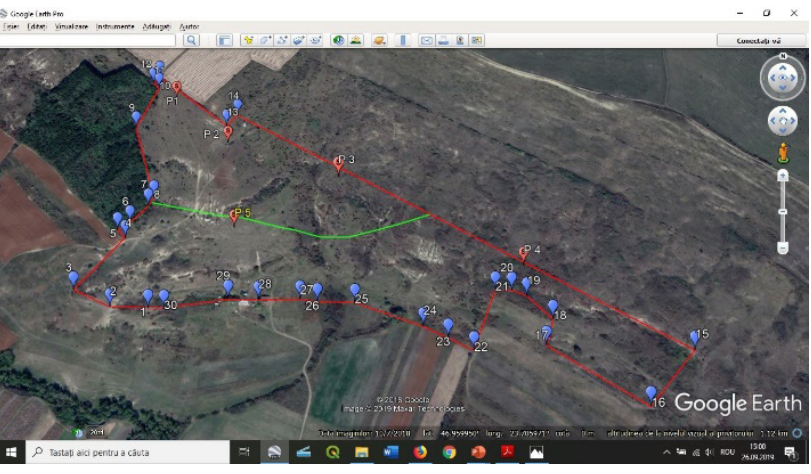

Figure 3. Upload GIS data to Google Earth

of the forest fund administered by the Gherla Forest District, Management Unit IV Panticeu, compartement 136, with the destination of the land being grassland (Fig. 1).

For establishing the afforestation solutions, the type of site and type of forest, respectively the production class were determined. To do this, bibliographic studies and field trips were made, in order to make observations on the natural environment (relief, hydrography and hydrology, pedological and climatic conditions).

Also, to determine the afforestation composition, soil samples were taken from four profiles, which were sent and analyzed in the laboratory.

Equipment used for field observations and determinations includes Trimble Yuma 2 field computer, digital pH meter, Google Earth and Qgis applications were used for data analysis.

The surface studied is situated in the Transylvanian Plain, according to "Geography of Romania" volume I, the area is characterized by 
Table 1. Monthly thermal regime

\begin{tabular}{|c|c|c|c|c|c|c|c|c|c|c|c|c|}
\hline \multirow{2}{*}{ Temperature } & \multicolumn{12}{|c|}{ Month } \\
\hline & I & II & III & IV & $\mathrm{V}$ & VI & VII & VIII & IX & $\mathrm{X}$ & $\mathrm{XI}$ & XII \\
\hline Medium temperature $\left({ }^{\circ} \mathrm{C}\right)$ & -3.2 & -0.6 & 4.8 & 9.8 & 14.8 & 17.5 & 19 & 18.7 & 15 & 9.6 & 3.6 & -0.9 \\
\hline Minimum temperature $\left({ }^{\circ} \mathrm{C}\right)$ & -6.8 & -4.6 & -0.3 & 4.2 & 8.8 & 11.7 & 13 & 12.5 & 9 & 4 & -0.1 & -3.9 \\
\hline Maximum temperature $\left({ }^{\circ} \mathrm{C}\right)$ & 0.5 & 3.4 & 10 & 15.5 & 20.8 & 23.3 & 25 & 24.9 & 21.1 & 15.2 & 7.3 & 2.2 \\
\hline
\end{tabular}

Table 2. The average temperature per season

\begin{tabular}{cccccc}
\hline $\begin{array}{c}\text { Average temp. on seasons and } \\
\text { vegetation period }\left(^{\circ}\right)\end{array}$ & Winter & Spring & Summer & Autumn & Vegetation period \\
\cline { 2 - 6 } \\
\hline
\end{tabular}

Table 3. Average monthly precipitation

\begin{tabular}{|c|c|c|c|c|c|c|c|c|c|c|c|c|}
\hline Month & I & II & III & IV & $\mathrm{V}$ & $\mathrm{VI}$ & VII & VIII & IX & $\mathrm{X}$ & $\mathrm{XI}$ & XII \\
\hline Precipitation (mm) & 34 & 30 & 28 & 47 & 75 & 87 & 80 & 68 & 39 & 37 & 37 & 41 \\
\hline
\end{tabular}

Table 4. Seasonal average rainfall

\begin{tabular}{|c|c|c|c|c|c|}
\hline \multirow{2}{*}{$\begin{array}{l}\text { Average rainfall during seasons and } \\
\text { vegetation period (mm) }\end{array}$} & Winter & Spring & Summer & Autumn & Vegetation period \\
\hline & 111 & 163 & 239 & 143 & 417 \\
\hline
\end{tabular}

fragmentation of land, narrow and wide valleys as it approaches the spillway, slopes with variable inclinations, but usually short, with frequent landslides, having altitudes between 200 and 400 meters.

The lithological substrate is made up of deluvial deposits composed of marls, clays, sandy loams with rich content of skeleton, of tuffs and dacites.

From a hydrographic point of view, the territory in which the land is found, is located in the basin of the Lona stream, the main tributary of the Someşul Mic river on its left side.

The hydrographic network is represented by the following valleys: Ungurului, Cacova, Calăcii, Sotelic, Recea, Elciu, Cubleș, Cristur, Cărbuniștea and Toaderii. The water supply of this hydrographic network is mixed, both pluvial and nival.

From a climatic point of view, the land is found in the climatic province Df, continental climate of hills, forest climate of the substrate 2.I. According to the Köppen-Geiger classification it belongs to the province D.f.k, characterized by a hill topoclimate with a moderate continental climate, the average annual temperature being $9^{\circ} \mathrm{C}$.

The average annual amplitude is $22.2^{\circ} \mathrm{C}$, the warmest month being July with an average of $19^{\circ} \mathrm{C}$, and the coldest is January with an average of $-3.2^{\circ} \mathrm{C}$. The average annual temperature is $8.2^{\circ} \mathrm{C}$. After the Koppen classification, the territory is in the type of climate Dfk and Df.b.k., where:

- D - rainy, boreal climate, with cold winters, the temperature of the coldest month is below $3^{\circ} \mathrm{C}$, and in the hottest month it is higher than $10^{\circ} \mathrm{C}$;

- $\mathrm{f}$ - sufficient rainfall throughout the year permanently humid area;

- B - the temperature in the hottest month is less than $22^{\circ} \mathrm{C}$ and in at least 4 months it is over $10^{\circ} \mathrm{C}$;

- $\mathrm{K}$ - cold winter, the average annual temperature is below $8^{\circ} \mathrm{C}$, the warmest temperature, less than $22^{\circ} \mathrm{C}$ and higher than $18^{\circ} \mathrm{C}$.

The average monthly precipitation is very varied, it records a maximum in May, June, July and a minimum in January and February (Tab. 3). The driest season is winter, when $16 \%$ of annual precipitation falls, and the rainiest is summer, with $30 \%$ of precipitation (Tab. 4).

During the vegetation period, the amount of precipitation reaches more than half of the annual total $(66 \%)$. The total of mean precipitations is $603 \mathrm{~mm}$.

The potential annual evapotranspiration varies between relatively close limits: 604-629 $\mathrm{mm}$. The excess water in the soil is until the beginning of the vegetation season - April and the 
Table 5. Synthetic indicators of humidity and aridity

\begin{tabular}{cccccc}
\hline Synthetic indicators & Annual & Spring & Summer & Autumn & Vegetation period \\
\hline Humidity index R=P/T & 73.5 & 72 & 56 & 41 & 56 \\
\hline Aridity index I=P/(T+10) & 33.13 & 34 & 35 & 24 & 33 \\
\hline
\end{tabular}

soil water deficit is relatively small and occurs at the end of the vegetation period - September.

The annual average of the De Martonne aridity index is 33.13 which confirms that these values indicate a surplus of water from rainfall compared to the potential evapotranspiration.

\section{Results}

The determination of the soil type was made initially on the field (Fig. 4) and subsequently, based on the laboratory results, two soil types were identified: Typical pelosol, having the succession of the Aoka-A/Cka-Cka horizons and the Marly phaeozem with the Aope-Btpe-Bt/Cca$\mathrm{Cca}$. These soil types have a high clay content, claydusty texture, and humus content is moderate (Tab. 6).

For pedo-stationary classification correlating the results obtained from the observations made on the environmental conditions, the main site characteristics were established:

a. Shape of relief: Corrugated slope;

b. Altitude: $325-400 \mathrm{~m}$;

c. Exposition: Southwest;

d. Inclination: $20 \mathrm{~g}$;

e. Functional category: grassland.

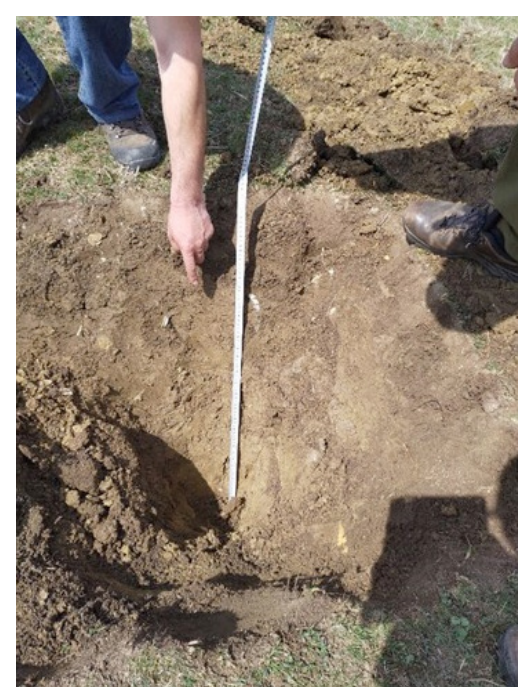

Figure 4. Soil profile
According to the above characteristics, the land taken in the study can fit into the type of site, according to the Romanian forest classification:

6.1.5.1 - Hilly of oaks (Turkey oak and Hungarian oak) Bi, brown, small edaphic (Tarziu, 1997) and the type of forest 7.1.1.3 - Hilly Turkey oak stand of inferior productivity (i).

The species corresponding to the site is Turkey oak, mixed with various typical species of hill mixed hardwood forest: flowering ash, field maple and pear-tree.

After identifying the types of site and forest, the ecological group was established on the basis of which the afforestation formula is established, according to the technical norms in use.

Thus in the studied area it was identified the Ecological Group 59, which established the afforestation formula 6 Ce (Go, Gî) 4 Ul.t, Mj, Ju, Pă, and the future forest is estimated to realize the fourth class of production.

The number of seedlings to be planted in the studied area is 75000 for Turkey oak (Sessile oak, Hungarian oak) and 50000 for Siberian elm, flowering ash, field maple and pear-tree.

\section{Conclusion}

The land that is the subject of the present study, is located the Dăbâca village, Cluj County, in a continental climate of hills.

The afforestation solution was established following bibliographic studies on the elements of the general natural environment in the area, associated with the microclimate and soil studies carried out in the planting area. They were also correlated with the technical norms in use regarding the establishment of plantations.

The main site characteristics obtained are: shape of relief corrugated slope, altitude between 325-400 m, exposition Southwest, inclination $20 \mathrm{~g}$, functional category grassland. The main climatic characteristics identified are average annual temperature $8.2^{\circ} \mathrm{C}$ and the annual average precipitation is $603 \mathrm{~mm}$.

The soil types identified are Ttypical pelosol, having the succession of the Aoka-A/Cka- Cka 


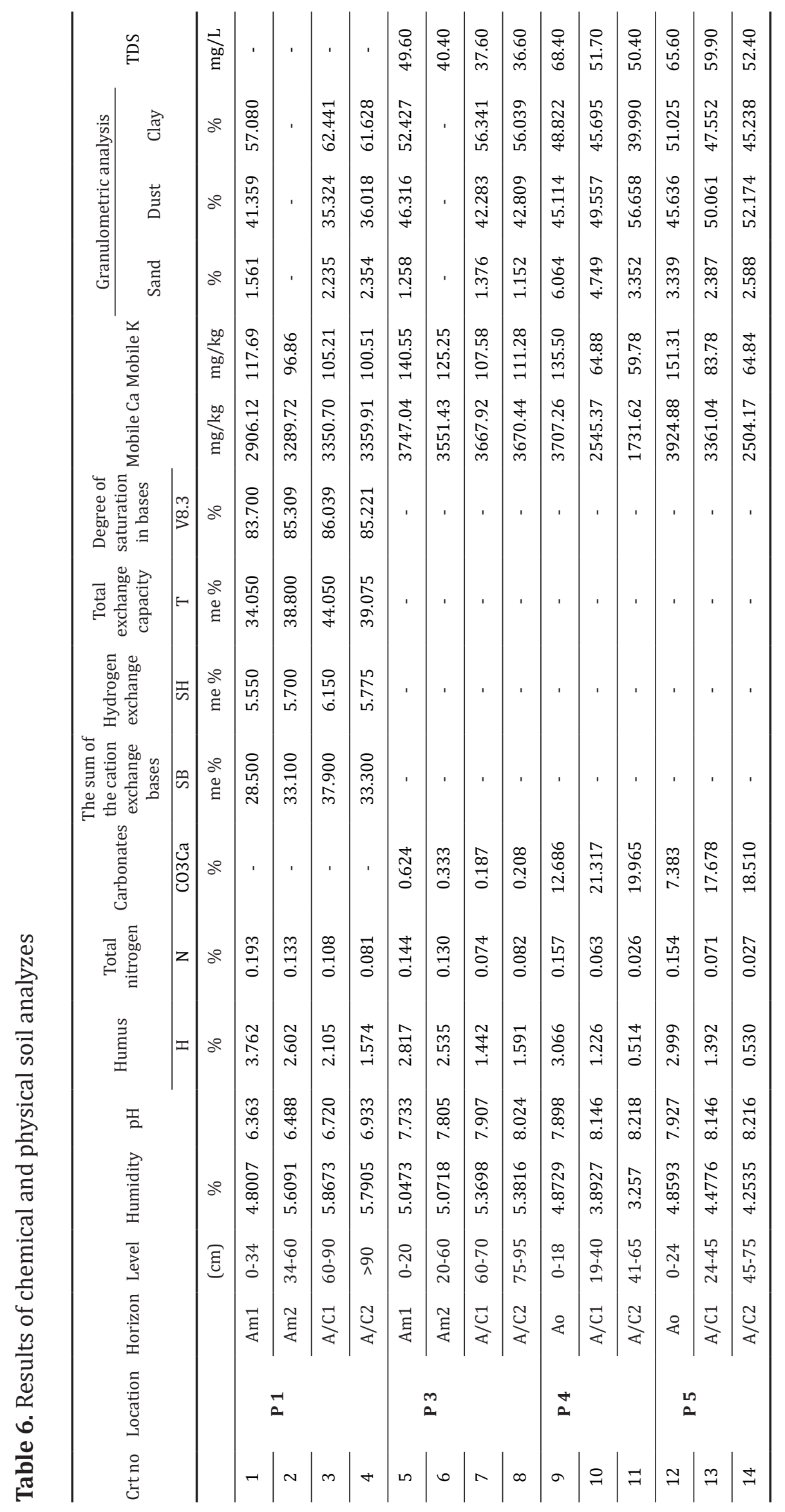


horizons and the Marly phaeozem with the AopeBtpe-Bt/Cca-Cca.

Combining the physico-climatic data with the soil types identified, the studied area was framed in the hilly region of oaks (Sessile oak, Turkey oak and Hungarian oak and mixtures between them) and hill mixed hardwood forest (FD2), the type of site being 6.1.5.1 - Hilly of oaks (Turkey oak and Hungarian oak) Bi, brown, small edaphic and the type of forest 7.1.1.3 - Hilly Turkey oak stand of inferior productivity (i). The species corresponding to the site is Turkey oak, mixed with various typical species of hill mixed hardwood forest: flowering ash, field maple and pear-tree.

After identifying the types of site and forest, the ecological group 59 was identified, which establishes the afforestation formula 6 Ce (Go, Gî) $4 \mathrm{Ul.t,} \mathrm{Mj}$, Ju, Pă, and the future forest is estimated to realize the fourth class of production.

The number of seedlings to be planted in the studied area is 75000 for Turkey oak (Sessile oak, Hungarian oak) and 50000 for Siberian elm, flowering ash, field maple and pear-tree.

\section{References}

1. Badea L, Gâștescu P, Velcea VA (1983). Geografia României volumul I, Editura Academiei R.S. România.

2. Constandache C, Blujdea V, Nistor S (2010). Achievements and Perspectives on the Improvement by Afforestation of Degraded Lands in Romania. In Land Degradation and Desertification: Assessment, Mitigation and Remediation 547-560 Springer, Dordrecht.

3. Keesstra SD, Bouma J, Wallinga J, Tittonell P, Smith P, Cerdà A, Montanarella L, Quinton JN, Pachepsky Y, van der Putten WH, Bardgett RD, Moolenaar S, Mol G, Jansen B, Fresco LO (2016). The significance of soils and soil science towards realization of the United Nations Sustainable Development Goals, SOIL 2: 111-128.

4. Keesstra S, Mol G, De Leeuw J, Okx J, Molenaar C, De Cleen M, Visser S (2018). Soil-Related Sustainable Development Goals: Four Concepts to Make Land Degradation Neutrality and Restoration Work. Land 7: 133.

5. Târziu D (1997). Pedologie şi staţiuni forestiere. București, Ed.Ceres.

6. Gianini T, Giulietti AM, Harley RM, Viana PL, Jaffe R, Alves R, Pinto CE, Mota NFO, Caldeira Jr CF, ImperatrizFonseca VL, Furtini AE, Siqueira JO (2017). Selecting plant species for practical restoration of degraded lands using a multiple-trait approach, Austral Ecology 42: 510-521

7. *** Norme tehnice privind compoziţii, scheme şi tehnologii de regenerare a pădurilor şi de împădurire a terenurilor degradate (2000). Ministerul Apelor, Pădurilor şi Protecţiei Mediului Inconjurător.

8. https://en.climate-data.org/europe/romania/cluj511/?page $=5$ Accessed 10 march 2019.

9. www.europa.eu/rapid/press-release_IP-18-4202_ro.pdf. 